\title{
Psychiatry in descent: Darwin and the Brownes
}

\author{
Toм WalmsLey, Consultant Psychiatrist, Knowle Hospital, Fareham PO17 5NA
}

Charles Darwin (1809-1882) enjoys an uneasy position in the history of psychiatry. In general terms, he showed a personal interest in the plight of the mentally ill and an astute empathy for psychiatric patients. On the other hand, he has generated derogatory views of insanity, especially through the writings of English social philosophers like Herbert Spencer and Samuel Butler, the Italian School of "criminal anthropology" and French alienists including Victor Magnan and Benedict Morel.

A contemporary demonstration of his ambiguous position is Elaine Showalter's widely praised account of British psychiatry from 1830 to 1980 (Showalter, 1987). Showalter introduces the concept of "psychiatric Darwinism" which, she explains, lasted from 1870 until 1920 and is to be understood in this way: "Following Darwin's theories of inheritance, evolution and degeneration, an emerging psychiatric Darwinism viewed insanity as the product of organic defect, poor heredity and an evil environment".

Thus far, few clinicians would take serious issue with Showalter although some might be uneasy about so-called "theories of degeneration". They, after all, were the product of social thinkers rather than Darwin himself. But then she continues: "Seeing the lunatic as a degenerate person of feeble will and morbid predisposition, Darwinian therapists took a dim view of asylum care and paternalistic therapy; instead they redefined their role as that of the psychiatric police, patrolling the boundaries between sanity and madness and protecting society from dangerous infiltration by those of tainted stock."

Who were these "Darwinian therapists"? Where did they spell out their opposition to asylum therapy? How did they protect society from tainted stock? Probably, Showalter is thinking of Henry Maudsley; but here she is in difficulty since Maudsley actively promoted the return of the insane to their own communities. Many of the other doctors she names - like Clouston - were asylum men unlikely to take "a dim view of asylum care". One is left with the impression that "psychiatric Darwinism" is a careless soubriquet for any psychiatric writing done in Britain from the death of Conolly in 1866 to the outbreak of the Great War in 1914. Showalter's polemic carries on to page 109 where we are introduced to "the Darwinian rhetoric of censure and disgust ... related to the political anxieties of the 1870 s and 1880s". (Darwin died in 1882).
Following this confident characterisation of the Darwinian view of insanity, it comes as a disappointment that Showalter fails to provide any quotations from his work; only one reference to his many publications in a bibliography running to 12 pages; and, in her general index, only five references to Darwin, all of them to secondary usages. (Interestingly, the last of these, on page 225, cites Darwin as part of R. D. Laing's "English classical education". One can imagine how Laing would have played with this bizarre misapprehension).

All of this might be forgiven were it not that Darwin held careful views concerning insanity, wrote much about it in his early notebooks and crowned his trilogy on natural selection with observations on mental patients. All in all, Charles Darwin has been poorly served by "Showalterian rhetoric".

\section{Janet Browne on Darwin}

Janet Browne (Browne, 1985) comes to Darwin altogether more squarely in her celebrated essay on Darwin and insanity.

"Darwin is not noted for his active participation in the world of medicine ... so it comes as something of a surprise to learn that Darwin did actively engage in one particular branch of medicine, the philosophical study of the insane ... and about contemporary theories of psychiatric diagnosis."

Browne outlines Darwin's thinking which led him to contact Sir James Crichton-Browne for information concerning the facial expressions associated with mental illness. In the composition of The Descent of Man, Darwin was anxious to put man himself at the centre of the struggle for survival and to emphasise the principle of sexual selection.

As he reviewed the secondary sexual characteristics of mankind, Darwin turned to the question of emotional expression and found a wealth of material which demanded a separate book. In this way, The Expression of the Emotions in Man and Animals became a separate and subsequent volume in the trilogy of natural selection history and was published in 1872.

Janet Browne shows how Darwin searched for examples of uninhibited emotional expression in primitive human groups, in babies and children, and, finally, in the insane. Darwin brought his own agenda to the study of insanity, seeking in Janet 
Browne's words: "a great finishing stroke to the arguments put forward in The Descent of Man ... intended to show that even the most 'human' characteristics were derived from animals ... he believed the emotions [of the insane] were uncontrolled and intense and that their faces would display their feelings in a pure, uncomplicated way, ideal for a scientific study of expression."

Sir James Crichton-Browne (1840-1938), the doctor chosen to supply the evidence, brought a different agenda to the project. Since the 18 th century, psychiatrists had sought evidence of the stigmata of lunacy in psychiatric illustration. Good examples are provided by the work of Tardieu for Esquirol and Gericault for Georget. The advent of photography, Crichton-Browne argued, supplied psychiatrists with an objective source of material to furnish a full and final taxonomy of mental disorder.

Janet Browne's essay records the failure of this project. Darwin, she shows, failed to find anything in Crichton-Browne's photography except the ordinary human expressions of suffering and despair and declined to include a chapter on mental diseases in his book. As she puts it, Darwin "completely failed to see the categories, the complex taxonomies that pervaded Crichton-Browne's corpus and underpinned nineteenth century theories of madness. Almost as if he were applying natural history concepts to the mentally ill, Darwin looked for evidence of 'species' madness and found none ... In the same way as he brought about the downfall of animal and plant classification schemes, Darwin exploded the taxonomy of insanity that lay behind almost every psychiatric endeavour of the later nineteenth century."

One wonders what Professor Showalter would make of this. However, Janet Browne provides us with a subsidiary theme of greater interest to psychiatrists. Most of Crichton-Browne's interpretations were incorporated into the book on expression and furthered Darwin's arguments in a way that he greatly appreciated. "I have been making immense use of your manuscript" wrote Darwin. "The book ought to be called by Darwin and Browne."

Janet Browne seems startled by this. "Such an extravagant compliment is, I believe, unique in Darwin's long writing career; he depended on Crichton-Browne's information and good judgement with a commitment rarely offered to scholars other than his closest friends. Browne was not a close friend of Darwin's which makes it all the more remarkable".

Here, after taking us so far, Janet Browne stumbles badly. Of course, Darwin and Crichton-Browne were no more than happy correspondents, but Darwin was well acquainted with the Browne family; he had been at Edinburgh Medical School with CrichtonBrowne's father, W.A.F. Browne; they had shared a mentor in Robert Grant; and they were the victims of a scandal in March 1827. Darwin learnt a great deal in his short time at Edinburgh; above all, he had learnt the methods of observation in natural history. The debating society for natural history was the Plinian Society; and its records show that Charles Darwin was proposed for membership in 1826 by W.A.F. Browne.

\section{The Sculling of W.A.F. Browne}

Widely recognised in his own lifetime (1805-1885) as one of the leading spokesmen for British asylum doctors, W.A.F. Browne has only recently re-emerged as a founding father of British psychiatry. Browne was the undergraduate President of Edinburgh's Royal Medical Society (1826/1828), a student of Esquirol's in Paris (1830), Physician-Superintendent of the Crichton Royal Institution (1838-1857) and President of the Medico-Psychological Association in 1866. However, he has only now achieved the supreme accolade for the Victorian alienist: a posthumous critical assault from Professor Andrew Scull (Scull, 1991).

In a sense, Scull makes heavy weather of it. His attempt to portray Browne as a conforming, selfseeking man of modest means from the genteel but financially precarious classes nearly rings true. But the idea that Browne chose insanity as a smart career move does not satisfy. Scull has nothing to say about Browne's friendship with Darwin and Robert Grant. Almost in spite of himself, Scull ends by endorsing Browne: "Browne's stress on social harmony and tranquillity; his claim to replace violent repression, conflict and strife by moral suasion, docility and willing submission to authority, even among the depraved and unruly; his practical demonstration of the powers of reason and morality when allied to a new kind of moral machinery - these constituted a potent advertisement for the merits of reformed asylums run by practitioners initiated into the mysteries of moral treatment and medical psychology. Accepting these claims ... the Victorian governing classes were provided with powerful incentives to embrace the lunacy reformers' schemes."

This is, quite simply, a full and frank assessment of Browne's claim for a moral approach to mental illness which was claimed by many and won by few. Scull contrasts the career of John Conolly (1794 1866) whose Construction and Government of Lunatic Asylums (1847) was obviously improved by a reading of Browne's What Asylums Were, Are and Ought to $B e$ (1837). Then he picks up Browne's weaknesses. Favouring the life of the country practitioner, Browne turned down senior jobs in Edinburgh and London. Scull - ever the sociologist - envisages Browne enjoying the phantom feudalism of his 
Dumfriesshire estates. But the facts of the industrial revolution came more suddenly and cruelly in Scotland than elsewhere and Browne's pastoral therapy in the valley of lower Nith supplied a kind of rural idyll recently popularised by Walter Scott whom Darwin glimpsed chairing the Royal Society of Edinburgh in 1826.

Scull is quick to recognise Brown's emphasis on the grouping and congregation of patients. Predictably, he regards this as shelving in the mental filing cabinets of Victorian alienists. Hunter \& Macalpine (1963) present an intriguing alternative: Browne foreshadowed modern techniques of group therapy and analysis. In fact, both are probably wrong. Browne's notion of adaptive association probably echoed Combe's phrenological doctrine of the brain as a "congerie" of organs.

Despite these errors, Scull's treatment of Browne is generally fair. His account of the later years (18701885 ) is crude; nor does he do justice to Browne's student years, the influential atheism and evolutionism of Robert Grant and the association with Darwin. In particular, Scull fails to mention the evening most momentous in Browne's life: 27 March 1827.

\section{March 1827}

In his autobiography (Darwin, 1887), Darwin seems almost forgetful about his Edinburgh days. In going to the medical school there, he was following a family tradition. But Darwin found the climate cruel, the town depressing and the teaching dull. Andrew Duncan (1744-1828), receives particularly harsh treatment: "Dr Duncan's lectures on Materia Medica at 8 o'clock on a winter's morning are something fearful to remember."

Darwin played down his Edinburgh days. But here he met Dr Robert Grant, the only teacher of evolutionary biology in the British Isles; and, in a way, Grant is an ancestor common to Darwin and Browne. "We walked by the seashore," wore Darwin "and Dr Grant showed me the technique of natural observation. When we were walking together, he burst forth in high admiration of Lamarck and his views of evolution. I listened in silent astonishment and as far as I can judge without any effect on my mind."

Darwin's studious amnesia is betrayed by the shocking events of the Plinian Society in the spring of 1827. With some nervousness, Darwin prepared his paper on the ciliary larvae of the Flustra organism under the close supervision of Grant. By chance, the other paper delivered on 27 March was W.A.F. Browne's speculative phrenological paper on the nature of mind. Browne believed the mind to be completely understandable in terms of material processes and relished a thorough demolition job on metaphysical and Christian fantasies. All this was too much for most Plinian members and uproar ensued. Browne fairly springs off the pages of Darwin's newest biographers (Desmond \& Moore, 1991): "Browne, the fiery radical, gave such an inflammatory harangue on matter and mind that it sparked a raging debate ... with no soul, no after-life, no punishment or reward, where was the deterrent against immorality?".

Professor Jameson, who had fostered the society, intervened to have all records of the meeting suppressed and Grant left Edinburgh in 1828 to take up the Chair of Zoology at University College London where he lost a war of attribution against Richard Owen. The effect on Darwin is difficult to gauge. He fails to detail this dreadful meeting in his autobiography and his recent biographers conclude simply that "in April 1827 he left Edinburgh for good - without a degree".

However, some Darwin scholars have attached more emphasis to the Plinian debacle. Gruber (1981) whose attention to Darwin's early writing is peerless, considers the Plinian row to have played a crucial role in Darwin's thinking and even in his psychological development.

\section{Plinian vestiges}

Darwin and Browne went their different ways. For Darwin, a half-hearted approach to the Church was followed by a great escape - a circumnavigation-where he was confined with the bipolar manic-depressive Captain Fitzroy. Like his uncle Castlereagh, the Foreign Secretary in Lord Liverpool's government, Fitzroy eventually took his own life by cutting his throat in 1865 , shortly after establishing the modern principles of weather forecasting.

Darwin's return to England was followed by his marriage and subsequent career as a secluded invalid punctuated by the rigours of hydropathic medicine and the secret elaboration of a theory of natural selection. Darwin's writing is not without literary admirers. In an ingenious piece of critical analysis (Beer, 1983), Gillian Beer notes how Darwin grasped the essential cliches of the Victorian novel and endowed mankind with a "secret legacy" magnified with a recklessness unknown to "other" Victorian novelists.

For Browne, there was continental study under Esquirol and Pariset, continuing phrenological involvement and, through his contacts with Andrew Combe, appointment to the medical superintendency of Montrose Asylum in 1834. Here, as Darwin returned to Falmouth and set up rooms in London in the autumn of 1836, Browne lectured the managers 
of the asylum in Montrose on the known facts concerning insanity and deplored the mad-house system of the 18th century. Then, in a short course of lectures, Browne outlined a great programme of asylum construction and reform. Following his appointment to the Crichton Royal in Dumfries and the birth of his eldest child James Crichton Browne (called after the pious benefactor of the Dumfries asylum) he continued a taxing programme of clinical duties till his preferment to Medical Commissioner in 1857.

We do not know the answer to the intriguing question: what did Browne make of the book on emotional expression published by his undergraduate friend Charles Darwin and his eldest son in 1872? Now a distinguished statesman of Victorian mental science, Browne was yet to hear of his son's succession to his presidency of the RMPA, a chapter unique in the history of this British institution later to become the Royal College of Psychiatrists. By this time, Browne was blind and tended by his wife and daughters. His mood was less mercurial, his outlook more conservative and an attitude of benevolent detachment seems to have settled on his final home on the northern outskirts of Dumfries.

\section{Conclusion: ancestors and descendants}

In the last 20 years or so, the practice of psychiatry in Victorian times has become something of a playground for social and cultural historians. The free play of ideas has opened up an atmosphere of vigorous debate about much of the medical malarkey of those times. The historians' view - at times explicit, more usually implied - is anti-medical in tone and extremely dismissive of doctors' attempts to account their own descent. In general, medical attempts at the history of medicine have been proven careless.

On the evidence of the Darwin case, as witnessed by Elaine Showalter, Janet Browne and Andrew Scull, it might be argued that the history of psychiatry is too important to be delegated to the historians. Yet such a judgement would be too harsh; it would be wrong. In 1990, Darwin's life was studied by the distinguished psychoanalyst John Bowlby (Bowlby, 1990). In a way, Bowlby was unlucky: within a year the biographical masterstroke was delivered by Adrian Desmond and James Moore at the conclusion of 15 years of study; and Bowlby, hopelessly outgunned, revealed the traditional preoccupations of the Freudian cognoscente, especially a wearisome rehearsal of Darwin's maternal deprivation. But Darwin, as Gillian Beer's study shows, stands up to all angles of approach, the psychoanalytic not excluded.

Charles Darwin bequeathed much to Freud and his followers. In various ways, the Darwinian bequest to asylum doctors was more powerful and less enlightening. For the Brownes - father and son - whose lives descended through the asylum era from 1805 to 1938 , the influence of Darwin was more personal. Through them, to British psychiatry today Darwin exerts an influence of a gentler and more intimate kind.

\section{Acknowledgements}

I am grateful to my colleagues Linda Hardwick and Charles Shawcross for their comments on the early versions of this assay.

\section{References}

BEER, G. (1983) Darwin's Plots: evolutionary narrative in Darwin, George Eliot and nineteenth century fiction. London: Routledge \& Kegan Paul.

BowLBY, J. (1990) Charles Darwin: a biography. London: Hutchinson.

BRowNE, J. (1985) Darwin and the face of madness. In The Anatomy of Madness, volume 1, (eds. Bynum, Porter and Shepherd). London: Tavistock.

DARWIN F. (ed) (1987) The Life and Letters of Charles Darwin, including an autobiographical chapter. London: Murray.

DeSMOND, A. \& MOORE, J. (1991) Darwin. London: Michael Joseph.

GRUBER, H. E. (1981) Darwin on Man: a psychological study of scientific creativity. Chicago: University of Chicago Press.

HuNTER, R. \& MACALPINE, I. (1963) Three Hundred Years of Psychiatry 1535-1860, pp. 865-869. London: Oxford University Press.

ScUll, A. (1991) The Asylum as Utopia: W.A.F. Browne and the mid-nineteenth century consolidation of psychiatry. London: Tavistock/Routledge.

Showalter, E. (1987) The Female Malady: women, madness and English culture 1830-1980. London: Virago Press. 